\title{
ARTIKULACIJSKO-FONOLOŠKE SPOSOBNOSTI DJECE S CEREBRALNOM PARALIZOM
}

\author{
EMICA FARAGO ${ }^{1}$, DRAŽENKA BLAŽII ${ }^{1}$, MARTINA VUKOVIĆ OGRIZEK ${ }^{2}$
}

${ }^{1}$ Edukacijsko rehabilitacijski fakultet, ${ }^{2}$ Poliklinika za rehabilitaciju slušanja i govora SUVAG, kontakt: emica.farago@gmail.com

Primljeno: 21.12.2015.

Izvorni znanstveni rad

Prihvaćeno: 22.2.2016.

UDK: $376.1-056.266$

SAŽETAK: Cilj ovog istraživanja bio je ispitati i usporediti artikulacijske i fonološke sposobnosti djece s cerebralnom paralizom s njihovim vršnjacima urednoga razvoja. Ispitivanje je provedeno na uzorku 15-ero djece s cerebralnom paralizom te 15-ero djece urednoga razvoja. Skupine su bile izjednačene po spolu i starosnoj dobi. Upotrijebljeni mjerni instrumenti sastojali su se od Testa artikulacije i zadataka za ispitivanje fonoloških vještina. Primijenjeni su relevantni statistički postupci (osnovni statistici, robusna diskriminativna analiza, t-test, hi-kvadrat test, Cochran-Cox metoda). Dobiveni rezultati ukazali su na postojanje statistickki značajnih razlika u artikulacijskim i fonološkim sposobnostima između djece s cerebralnom paralizom (CP) $i$ djece urednoga razvoja (UR). Razlikovanju skupina, u manifestnom prostoru, u najvećoj mjeri pridonose varijable brisanje konsonanata (BRISK) te broj artikulacijskih pogrešaka (TESTA). U kreiranju diskriminacijske funkcije značajno sudjeluju i varijable: izdvajanje početnoga glasa (IZPG), fonemska analiza (FONAN) i traženje rime (TRAR).

Rezultati potvrđuju i statistički značajne razlike u artikulacijskim i fonološkim sposobnostima prema tipu cerebralne paralize. Skupina djece sa spastičnim tipom cerebralne paralize bila je uspješnija u zadatcima koji su ispitivali fonemsku analizu (FONAN), rastavljanje na slogove, brisanje konsonanata (BRISK), traženje rime (TRAR) te su imali bolje artikulacijske sposobnosti.

Ključne riječi: cerebralna paraliza, fonološke sposobnosti, artikulacija

\section{UVOD}

Dječja cerebralna paraliza (moždana klijenut) poremećaj je pokreta i posturalne ravnoteže i spada u skupinu trajnih poremećaja razvoja pokreta i posture koji uzrokuju ograničenja u izvođenju aktivnosti, a posljedica su neprogresivnih poremećaja nezrelog mozga ili mozga u razvoju. Motorički poremećaji kod cerebralne paralize često su udruženi s poremećajima osjeta, percepcije, kognicije, komunikacije i ponašanja, epilepsijom i sekundarnim mišićnokoštanim problemima (Bax i sur., 2005, Himmelmann i sur. 2010). Prema Križ i Prpić (2005) cerebralna paraliza (CP) javlja se u 3 do 5 slučajeva na 1000 živorođene djece, dok Pospiš (2005) iznosi podatak o 5 djece s CP-om na 2000 živorođene novorođenčadi. Incidencija $\mathrm{CP}-\mathrm{a}$ znatno je viša u prijevremeno rođene djece i povećava se sa smanjenjem porođajne težine i gestacijske dobi. Iako često promjenjivih motoričkih manifestacija, ograničenja u motoričkim funkcijama uslijed pareza i paraliza osnovni su simptomi cerebralne paralize koji se mogu javi- ti udruženo sa smetnjama neke druge vrste kao npr. oštećenje vida, sluha, intelektualne teškoće te smetnje u ponašanju. Jezično-govorne i komunikacijske teškoće učestali su prateći simptomi cerebralne paralize i vidljvi su od najranije dobi djeteta. Poznato je da djeca s cerebralnom paralizom kasne u govornom, ali i jezičnom razvoju, a ovisno o uzroku i težini oštećenja to kašnjenje može biti i do tri godine u odnosu na djecu urednog razvoja (Kirinčić i sur., 1992, Bax i sur., 2005, Pennington, 2008, Nordberg, 2015). Manifestacije i teškoće u području jezično-govornih sposobnosti djece s cerebralnom paralizom mogu biti različite. Tako neka djeca nisu u stanju koristiti jezik (putem govora) u svrhu komunikacije, druga skupina djece to ostvaruje ali vrlo otežano, a treća (malobrojnija) skupina nema narušenu jezično-govornu uporabu i komunicira na razini zadovoljavajućeg inteligibiliteta. Djeca s cerebralnom paralizom rijetko započinju konverzaciju, produciraju mnogo kratkih da/ ne odgovora te imaju teškoće u razvoju narativnih vještina i funkcionalne komunikacije. Teškoće $u$ ostvarivanju komunikacije često su rezultat moto- 
ričkih oštećenja i oštećenja neuromuskulatorne kontrole govornog mehanizma. Govorni mehanizam uključuje četiri procesa: jezično procesiranje, u kojem se sadržaj izraza pretvara u fonemske simbole u jezičnom centru u mozgu; stvaranje motoričkih naredbi koje su upućuju govornim organima iz motoričkog moždanog centra; artikulacijske pokrete govornih organa za produkciju govora utemeljenu na motoričkim naredbama i emisije zraka poslanog iz pluća u obliku govora (Honda, 2003). Artikulacija je prema tome motorički čin koji uključuje niz procesa. Iz tog razloga motorička funkcija ima osobit značaj u glasovnoj i govornoj proizvodnji. Budući da osobe s cerebralnom paralizom imaju teškoća na različitim motoričkim razinama ovisno o topografiji i opsegu neuromuskularnog oštećenja javljaju se i različiti stupnjevi i vrste manifestacija što se različito odražava na glasovnu produkciju, odnosno artikulaciju. Za dobru artikulaciju pored spomenutih komponenti potrebna je i dobra mišićna pokretljivost, koordinacija mišića i mišićnih skupina svih funkcionalnih komponenti koje sudjeljuju u procesu glasovne proizvodnje.

Stoga se smatra da se narušena neuromišićna kontrola govornog mehanizma negativno odražava na govorno-glasovnu produkciju, odnosno pogađa govornu razumljivost (Nordberg i sur., 2014).

Govorna razumljivost u izravnoj je vezi s artikulacijskom preciznošću a prema istraživanjima (Peeters i sur., 2008), artikulacijska preciznost povezana je s razinom fonološke svjesnosti. Taj nam podatak govori da osim neuromišićne kontrole postoje i drugi čimbenici koji mogu utjecati na uspješnost u govornoj produkciji.

Fonološka svjesnost opći je izraz koji uključuje vještine otkrivanja, razlikovanja i manipuliranja sastavnim glasovima u riječima, slogovima, onsetima, rimom i fonemima. Niz istraživanja metalingvističkih sposobnosti djece predškolske i školske dobi (Cowan i Moran,1997, Bowen, 1998a, 1998b, Blaži i sur., 2000, Munson i sur., 2005a, 2005b, Storkel i Hoover, 2009, Blaži i sur., 2011) ukazuju na čvrstu poveznicu između poteškoća u oblikovanju i prizvodnji glasova i fonološke svjesnosti te potvrđuju pretpostavku da kognitivna svijest o "uzorku glasa" pogoduje razvoju i dovodi do pojave ispravnih govornih pokreta. Istraživanja poveznica sposobnosti fonološke svjesnosti u različitim jezičnim okruženjima pokazala su da vježbe u području fonološke obrade poboljšavaju sposobnost dekodiranja novih riječi, a time poboljšavaju i čitalačke vještine (Nicholson, 1997, Vancaš i Ivšac, 2004., Lenček i sur. 2007.). Pored govornog u komunikaciji važnu ulogu ima i pisani jezik. Razina postignuća u pisanom jeziku izrazito snažno pozitivno korelira s akademskim postignućem. Jedan od značajnih prediktora u razvoju pisanog jezika pripada opet fonološkoj svjesnosti. (Apel i sur., 2004; Kirby i sur., 2003, Rvachew i sur., 2003). U pregledu istraživanja o povezanosti govornog i pisanog jezika uočavaju se trendovi prema kojima djeca koja imaju teškoće u području govorne produkcije imaju evidentirane teškoće i s fonološkom svjesnošću i kasnije probleme u svladavanju pisanog jezika. (Menyuk, Chesnik, 1997). Upravo ta činjenica ističe značaj sposobnosti fonološke svjesnosti i artikulacije glasova djece s cerebralnom paralizom jer tehnološke mogućnosti svakim danom otvaraju sve veći prostor za alternativne načine komunikacije gdje upravo vještine čitanja i sricanja imaju značajnu ulogu.

\section{CILJ ISTRAŽIVANJA I PRETPOSTAVKE}

Cilj ovog istraživanja bio je ispitati i usporediti artikulacijske i fonološke sposobnosti djece s cerebralnom paralizom s njihovim vršnjacima urednoga razvoja.

\section{HIPOTEZE}

Postavljene su dvije pretpostavke:

H1: Postoje statistički značajne razlike u artikulacijskim i fonološkim sposobnostima između djece s cerebralnom paralizom i djece urednoga razvoja.

H2: U skupni djece s cerebralnom paralizom postoji statistički značajna razlika u artikulacijskim i fonološkim sposobnostima u odnosu na tip cerebralne paralize (spastična -atetoza).

\section{METODE RADA}

Uzorak ispitanika. Ispitivanje je provedeno na ukupno 30-ero djece školskog uzrasta, 14 dječaka i 16 djevojčica. Ispitanici su podijeljeni u dvije sku- 
pine. Prvu je skupinu činilo 15-ero djece s cerebralnom paralizom kod koje je utvrđeno da se radi o urednom intelektualnom statusu (CP) i 15-ero njihovih vršnjaka urednog motoričkog i intelektualnog razvoja (UR). Raspon dobi ispitanika kretao se od 9;00 godina do 14;00 godina, s prosječnom dobi od 11,5 u obje skupine. Od 15 ispitanika u skupini djece s CP-om samo jedno dijete imalo je monoplegiju, a svi ostali imali su tetraplegiju. Prema tipu cerebralne paralize petero djece imalo je atetotički (ACP), a desetero spastični oblik (SCP) cerebralne paralize. Skupine djece s CP i djece urednog razvoja su usklađene po dobi i spolu. Ispitivanje je provedeno u Specijalnoj bolnici za djecu s motoričkim smetnjama, Goljak 2, u Zagrebu i u Centru za rehabilitaciju na Edukacijsko- rehabilitacijskom fakultetu.

Mjerni instrumenti. S obzirom na postavljeni cilj i hipoteze istraživanja, ispitivanje je provedeno pomoću devet zadataka koji su sastavljeni za potrebe ovog istraživanja a prema predlošku sličnih zadataka koji se uobičajeno koriste za ispitivanje ovih vještina i sposobnosti. Upotrijebljeni mjerni instrumenti sastojali su se od Testa artikulacije i zadataka za ispitivanje fonoloških vještina.

- Test artikulacije načinjen je po uzoru na Test artikulacije (Vuletić, 1990), a sadržavao je listu od 66 riječi koje su sadržavale sve glasove hrvatskog standardnog jezika u sve tri pozicije u riječi, inicijalnoj, medijalnoj i finalnoj i svaka riječ je bila popraćena slikovnim materijalom. Dijete je imalo zadatak imenovati što vidi na slici, a njegovi odgovori upisivani su u za to posebno konstruiran obrazac.

Zadaci za ispitivanje fonoloških sposobnosti uključivali su ponavljanje riječi i logatoma, traženje rime, rastavljanje na slogove, aliteraciju, fonemsku analizu i sintezu te brisanje konsonanata u riječi. Svi odgovori upisivani su u za to posebno konstruiran obrazac .

- ponavljanje riječi - zadatak ponavljanja riječi preuzet je iz Testa artikulacije (Vuletić, 1990) pri čemu su riječi poredane od lakših prema težima. Ispitivač je izgovarao riječ po riječ samo jednom, bez ponavljanja, a ispitanik je imao zadatak ponoviti riječ. U ovom zadataku u obzir su uzimane greške omisije, supstitucije, adicije i metateze glasova i slogova, ali ne i pogrešno izgovoreni glasovi koji u ispitanika pripadaju u njegov poremećaj izgovora (preuzeto iz Test artikulacije (Vuletić, 1990)).

- ponavljanje pseudoriječi - zadatak ponavljanja pseudoriječi također je preuzet iz Testa artikulacije (Vuletić, 1990) i pseudoriječi su bile poredane od lakših prema težima. Način provođenja ispitivanja i vrednovanja rezultata jednak je kao kod zadatka ponavljanja riječi.

- traženje rime - u zadatku traženja rime ispitaniku su ponuđene tri slike između kojih je trebao pokazati koja dva pojma prikazana na slikama se rimuju (npr. ponuđene su riječi list - deva - kist popraćene slikovnim materijalom, a ispitanik je trebao odgovoriti da se rimuju riječi list i kist). Zadatak se sastojao od četiri dijela:

1. list - kist - deva

2. $\operatorname{sir}-$ žir - miš

3. krava - kuća - trava

4. limun - majmun - gušter

- rastavljanje na slogove - u ovom zadatku ispitaniku je ponuđeno pet riječi, od čega tri dvosložne i dvije trosložne (KV) koje je trebao rastaviti na slogove.

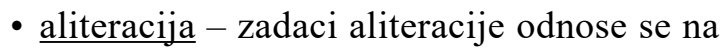
prepoznavanje i izdvajanje početnoga glasa u riječi. U ovom zadatku ispitanik je trebao pokazati sliku koja započinje zadanim fonemom. Zadani fonemi bili su:

- A - vokal, moguće mu je produžiti vrijeme fonacije pa postaje jako uočljiv u inicijalnoj poziciji i najučestaliji je glas u hrvatskom jeziku (Vuletić, 1990). Zadane su riječi: auto, avion, antena.

- P - konsonant, okluziv, bilabijal i samim time vizualno vrlo uočljiv te jedan od prvih glasova koje dijete usvaja. Zadane su riječi: palma, ptica, pas.

- K - konsonant, okluziv, velar i iako auditivno teže uočljiv, jedan je od najčešćih konsonanata u hrvatskom jeziku (Vuletić, 1990). Zadane su riječi: krava, kokoš, krevet.

- L - konsonant, sonant pa mu je moguće produžiti vrijeme fonacije, a po auditivnosti je odmah iza vokala. Zadane su riječi: lopta, list, lastavica. 


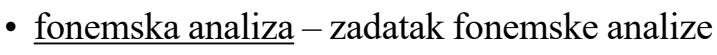
sadržavao je osam riječi, poredanih od kraćih prema duljima, od riječi s tri fonema do riječi sa šest fonema. Odabrane su dvije kombinacije riječi - riječi koje se sastoje od konsonant + vokal skupine i riječi koje se sastoje od konsonant + konsonant skupine. Zadane su riječi: pas, vrt, noga, stol, konac, glava, žirafa, trešnja. Ispitivač je izgovorio riječ, a ispitanik je trebao raščlaniti zadanu riječ na glasove.

- fonemska sinteza - zadatak fonemske sinteze također je sadržavao osam riječi koje je ispitivač izgovorio kao seriju fonema (jednu po jednu riječ), a ispitanik je trebao reći koja riječ je izgovorena. Pritom se poštivalo načelo postupnosti (od riječi s manje fonema do riječi s više fonema) te su korištene kao i u prethodnom zadatku dvije kombinacije riječi - riječi koje se sastoje od konsonant + vokal skupine i riječi koje se sastoje od konsonant + konsonant skupine. Zadane su serije fonema: s-a-t, c-r-v, m-a-m-a, d-r-v-o, l-i-m-u-n, t-r-av-a, j-a-b-u-k-a, p-j-e-s-m-a.

- brisanje konsonanata - u ovom zadatku ispitivač je izgovorio zadanu riječ, a ispitanik je trebao reći koja riječ nastane ako iz prvotne riječi izbrišemo određeni konsonant, npr. koja riječ nastaje ako iz riječi brod obrišemo glas $r$ ? Zadani su parovi riječi:

- kost - kos

- brak - rak

- brod - bod

- žlica - žica.

Svako je dijete ispitivano zasebno, a odgovori djeteta su odmah zapisivani u konstruirane obrasce ovisno o postavljenom zadatku.

\section{Varijable istraživanja}

Sukladno primijenjenom instrumentariju definirane su i varijable istraživanja:

TESTA - test artikulacije

PONAR - ponavljanje riječi

PONAP - ponavljanje pseudoriječi

TRAR - traženje rime

IZPG - izdvajanje početnoga glasa
RASTS - rastavljanje na slogove

FONAN - fonemska analiza

FONSI - fonemska sinteza

BRISK - brisanje konsonanata

\section{Način obrade podataka.}

Za obradu prikupljenih podataka korišteni su standardni parametrijski i neparametrijski statistički postupci, pretežno u SPSS-u. Izračunati su osnovni statistički parametri a ispitana je i normalnost distribucije frekvencija intervalne varijable TEST A, za svaku pojedinu skupinu ispitanika, pomoću Kolmogorov-Smirnov i Shapiro-Wilk testa. Za sve ostale varijable koje su dihotomnog tipa izračunate su frekvencije i postoci ispitanika po kategorijama, posebno za svaku skupinu ispitanika. Budući da su u istraživanje uključene dvije manje skupine ispitanika - djeca s cerebralnom paralizom i njihovi vršnjaci urednoga razvoja, dobiveni podaci su obrađeni i robusnom diskriminacijskom analizom. Statističku značajnost razlika između aritmetičkih sredina intervalne varijable TEST A provjerili smo t-testom za nezavisne uzorke, a zbog malog broja ispitanika primijenjena je CochranCox metoda. Razlike između skupina na ostalim manifestnim varijablama (dihotomnim) ispitane su neparametrijskom metodom i to primijenom Hi-kvadrat testa.

\section{REZULTATI I RASPRAVA}

\section{Osnovni statistički pokazatelji}

Već je ranije spomenuto da govornu produkciju u jednom dijelu možemo smatrati motoričkim činom. Zbog primarnog motoričkog oštećenja koje može narušiti neuromišićnu kontrolu govornog mehanizma bilo je za pretpostaviti da će djeca $\mathrm{s}$ cerebralnom paralizom imati teškoće $u$ ispravnom oblikovanju glasova a s tim u svezi i značajno više pogrešaka u artikulaciji glasova u odnosu na skupinu djece urednog razvoja. Iz tog razloga moguće je i značajno odstupanje u govornom inteligibilitetu. U tom svjetlu mogu se gledati i rezultati dobiveni ovim istraživanjem.

Varijabla TEST A (test artikulacije - broj gre$\check{s} a k a)$ je intervalna te smo uz izračunavanje osnov- 
Tablica 1. Osnovni statistički parametri i testiranje normalnosti distribucija frekvencija (Shapiro-Wilk test) za osobe s cerebralnom paralizom (CP) $i$ osobe urednog razvoja (UR)

\begin{tabular}{|l|c|c|c|c|c|c|c|c|c|c|}
\hline Varijabla & \multicolumn{2}{|c|}{$\begin{array}{c}\text { Aritmetičke } \\
\text { sredine }\end{array}$} & \multicolumn{2}{c|}{$\begin{array}{c}\text { Standardne } \\
\text { devijacije }\end{array}$} & \multicolumn{2}{c|}{$\begin{array}{c}\text { Najmanji } \\
\text { rezultati }\end{array}$} & \multicolumn{2}{|c|}{ Najveći rezultati } & $\begin{array}{c}\text { Shapiro-Wilk test } \\
\text { (Sig.) }\end{array}$ \\
\cline { 2 - 10 } & CP & UR & CP & UR & CP & UR & CP & UR & CP & UR \\
\hline $\begin{array}{l}\text { TEST A } \\
\text { (Test artikulacije) }\end{array}$ & 20,87 & 4,73 & 9,67 & 5,69 & 0 & 0 & 36 & 21 & 0,442 & 0,003 \\
\hline
\end{tabular}

nih statističkih parametrara testirali normalnost distribucija frekvencija za svaku skupinu ispitanika. Rezultati su prikazani u Tablici 1.

Iz tablice proizlazi da je kod osoba s CP prosječan broj grešaka na testu artikulacije 20,87 uz standardnu devijaciju od 9,67. Distribucija frekvencija, kako je pokazao Shapiro-Wilk test, normalna je (Sig.>5\%). Kod osoba urednog razvoja prosječan broj grešaka iznosi 4,73 uz standardnu devijaciju od 5,69. Shapiro-Wilk test normalnosti distribucije frekvencija pokazuje da distribucija odstupa značajno od normalne (Sig. $<5 \%$ ).

Rezultati dobiveni na zadatcima koji ispituju artikulacijske vještine ukazuju na bolji izgovor glasova djece urednog razvoja (UR). Bitne razlike uočene su u unutrašnjoj distribuciji pogrešaka jer deset ispitanika urednog razvoja imalo je najviše četiri pogreške na ukupno 66 riječi, dok je samo jedan ispitanik imao 21 pogrešku. U skupini osoba s CP-om, broj pogrešaka u izgovoru kod pojedinog ispitanika bio je između 0 (samo jedan ispitanik) $\mathrm{i}$ 36 (Grafikon 1 i 2).

Veliko raspršenje rezultata unutar skupina te kvalitativna analiza vrste učinjenih artikulacijskih pogrešaka ukazuju na određene razlike između skupina. Niti u jednoj skupini nisu registrirane omisije što je bilo za očekivati s obzirom na starosnu dob u kojoj se više ne očekuje izostavljanje glasova. Kod ispitanika urednoga razvoja nalazimo isključivo distorzije i to u skupini sigmatizma i rotacizma. Međutim, kod ispitanika s cerebralnom paralizom, uz distorzije koje su prisutne u puno većem broju i širem rasponu zahvaćenosti glasovnih skupina, nalazimo i supstitucije ( Grafikon 3).

Preostale varijable istraživanja su ordinalne sa samo dvije kategorije, tj. dihotomne s kategorijama: 1-ima grešku, 2-nema grešku. Osnovni statistički pokazatelji za preostalih 8 manifestnih varijabli su frekvencije i postoci po kategorijama svake varijable, posebno za svaku ispitanu skupinu (CP i UR). Postoci odgovora ispitanika po svakoj navedenoj kategoriji manifestnih varijabli prikazani su tabelarno i grafički ( Tablica 2., Grafikon 4)

Iz tablice 2 je vidljivo da su osobe s cerebralnom $(\mathrm{CP})$ na navedenim varijablama učinile od

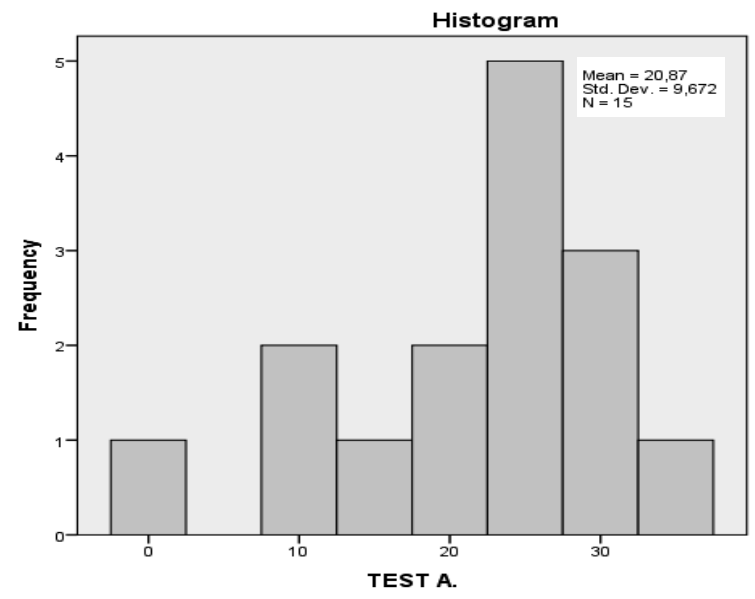

Grafikon 1. Prikaz rezultata varijable TEST A za osobe s $C P$

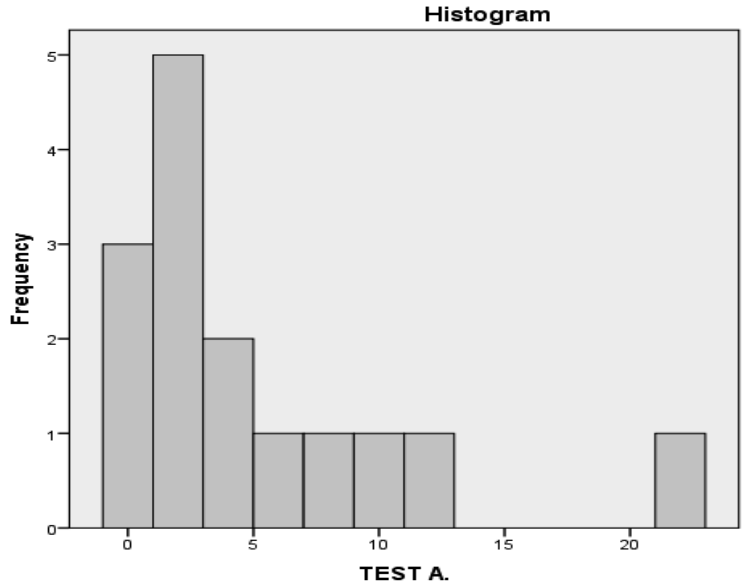

Slika 2. Grafikon 1. Prikaz rezultata varijable TEST A za osobe UR 


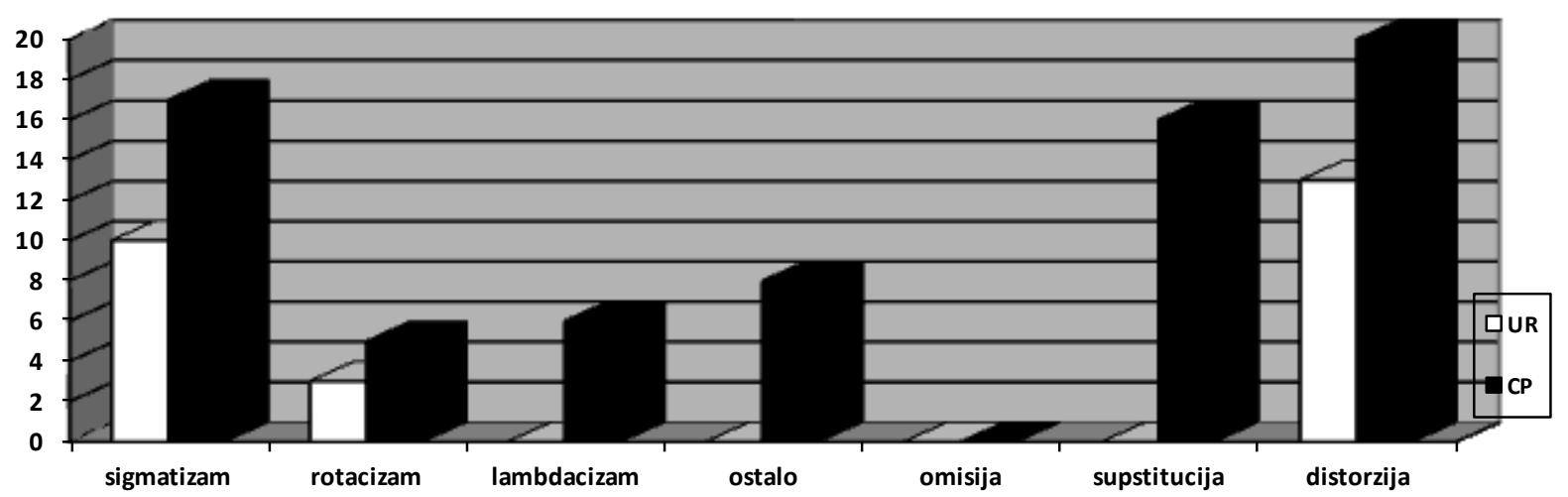

UR - ispitanici urednog razvoja; CP - ispitanici s cerebral nom paralizom

Grafikon 3. Prikaz artikulacijskih pogrešaka prema vrsti i stupnju

Tablica 2. Frekvencije i postoci odgovora osoba s CP i osoba UR po kategorijama svih manifestnih dihotomnih varijabli

\begin{tabular}{|l|c|c|c|c|}
\hline \multirow{2}{*}{ Varijable } & $\begin{array}{c}\text { CP } \\
\text { osobe s cerebralnom paralizom: } \\
\text { frekvencija/postotak }\end{array}$ & \multicolumn{2}{c|}{$\begin{array}{c}\text { UR } \\
\text { osobe urednog razvoja: } \\
\text { frekvencija/postotak }\end{array}$} \\
\cline { 2 - 5 } & 1-ima grešku & 2-nema grešku & 1-ima grešku & 2-nema grešku \\
\hline PONAR - ponavljanje riječi & $2 / 13$ & $13 / 87$ & $0 / 0$ & $15 / 100$ \\
\hline PONAL - ponavljanje logatoma & $9 / 60$ & $6 / 40$ & $5 / 33$ & $10 / 67$ \\
\hline TRAR - traženje rime & $9 / 60$ & $6 / 40$ & $3 / 20$ & $12 / 80$ \\
\hline IZPG - izdvajanje početnoga glasa & $9 / 60$ & $6 / 40$ & $0 / 0$ & $15 / 100$ \\
\hline RASTS - rastavljanje na slogove & $4 / 27$ & $11 / 73$ & $1 / 7$ & $14 / 93$ \\
\hline FONAN - fonemska analiza & $8 / 53$ & $7 / 47$ & $2 / 13$ & $13 / 87$ \\
\hline FONSI - fonemska sinteza & $3 / 20$ & $12 / 80$ & $0 / 0$ & $15 / 100$ \\
\hline BRISK- brisanje konsonanata & $11 / 73$ & $4 / 27$ & $0 / 0$ & $15 / 100$ \\
\hline
\end{tabular}

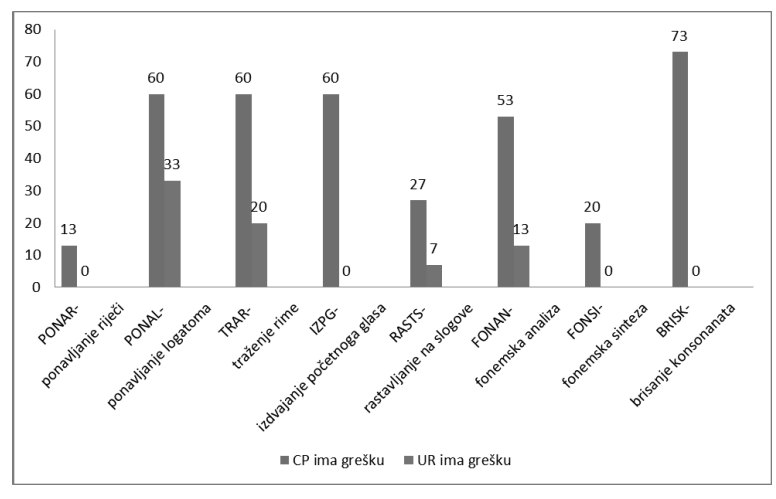

Grafikon 4. Postoci grešaka koje su učinile osobe s CP i osobe UR na svakoj manifestnoj dihotomnoj varijabli

$13 \%$ do $73 \%$ pogrešaka, dok su osobe urednog razvoja (UR) na svim varijablama učinile od $0 \%$ do najviše $33 \%$ pogrešaka.

\section{Razlike u artikulacijskim i fonološkim sposobnostima između djece $s$ cerebralnom paralizom (CP) i djece urednog razvoja (UR)}

Iako su artikulacijske vještine uglavnom pod motoričkom kontrolom, često na izgovor glasova utječu i drugi čimbenici kao npr. teškoće u auditivnoj percepciji glasa što se nadalje reflektira i na usvajanje pogrešne slike glasa te na ostale fonološke vještine. U mnogim istraživanjima nalazi se vrlo snažna poveznica između artikulacijskih sposobnosti uvjetovanih upravo tom fonološkom komponentom i fonološkom svjesnosti. Stoga smo željeli utvrditi relacije između spomenutih sposobnosti u skupini djece s cerebralnom paralizom (CP) i skupini djece urednog razvoja (UR).

U svrhu testiranja značajnosti razlika između obje skupine ispitanika, tj. hipoteze H1, korište- 
Tablica 3. Rezultati robustne diskriminacijske analize između djece s CP i djece urednog razvoja

\begin{tabular}{|c|c|c|c|c|c|c|c|}
\hline \multicolumn{2}{|c|}{ Diskriminacijska } & \multicolumn{2}{c|}{$\begin{array}{c}\text { Aritmetičke sredine } \\
\text { (Centroidi) }\end{array}$} & \multicolumn{2}{c|}{ Standardne devijacije } & F & P \\
značajnost \\
\cline { 1 - 5 } funkcija & vrijednost & CP (1) & UR (2) & CP (1) & UR (2) & & \\
\hline I. & 4,42 & 1,49 & $-1,49$ & 1,73 & 0,51 & 40,31 & 0,000 \\
\hline
\end{tabular}

na je diskriminacijska analiza. Budući da zavisne varijable, kod obe skupine ispitanika, nisu normalno distribuirane potrebno je bilo obraditi podatke programom za robusnu diskriminacijsku analizu ROBDIS (Nikolić, 1991, prema Mejovšek, 2013). Rezultati su prikazani u Tablici 3.

Ekstrahirana je jedna diskriminacijska funkcija, te su izračunate aritmetičke sredine (centroidi) u Z-vrijednostima na diskriminacijskoj funkciji za djecu s cerebralnom paralizom (CP) i djecu urednog razvoja (UR), na zajedničkom skupu artikulacijskih i fonoloških, a ujedno i zavisnih varijabli. Isto tako izračunate su standardne devijacije, F test (Fisherov) i pogreška koje se čini prilikom odbacivanja H1 hipoteze, tj. značajnost razlika p. Diskriminacijska funkcija značajna je na razini $p=0,000$. Centroidi ili prosječne vrijednosti na diskriminacijskoj funkciji međusobno su udaljene 2,98 standardnih devijacija. Temeljem navedenog može se prihvatiti hipotezu H1 te zaključiti da postoje statistički značajne razlike u artikulacijskim i fonološkim sposobnostima između djece s cerebralnom paralizom (CP) i djece urednoga razvoja (UR). Djeca s cerebralnom paralizom učinila su prosječno veći broj artikulacijskih i

Tablica 4. Struktura diskriminacijske funkcije

\begin{tabular}{|l|c|c|}
\hline Varijable & $\begin{array}{c}\text { Diskriminacijski } \\
\text { koeficijenti }\end{array}$ & $\begin{array}{c}\text { Korelacije s diskr. } \\
\text { funkcijom }\end{array}$ \\
\hline TESTA & .49 & .77 \\
\hline PONAR & -.18 & -.51 \\
\hline PONAL & -.18 & .48 \\
\hline TRAR & -.27 & -.64 \\
\hline IZPG & -.44 & -.77 \\
\hline RASTS & -.18 & -.59 \\
\hline FONAN & -.29 & -.70 \\
\hline FONSI & -.22 & -.61 \\
\hline BRISK & -.51 & -.86 \\
\hline
\end{tabular}

fonoloških grešaka (1,49 standardnih devijacija) od djece urednog razvoja (-1,49 standardnih devijacija).

Kao što je vidljivo u Tablici 4, u kreiranju diskriminacijske funkcije najviše sudjeluje varijabla brisanje konsonanata (BRISK) s diskriminacijskim koeficijentom -0,51 i vrlo visokom korelacijom s diskriminacijskom funkcijom od -0,86. $\mathrm{U}$ definiranju diskriminacijske funkcije značajno sudjeluje i varijabla TESTA (broj artikulacijskih pogrešaka), čiji diskriminacijski koeficijent iznosi 0,49 a korelacija s diskriminacijskom funkcijom 0,77 . Uz ove varijable u kreiranju diskriminacijske funkcije značajno sudjeluju i varijable: $i z d v a-$ janje početnoga glasa (IZPG), fonemska analiza (FONAN), traženje rime (TRAR). Ostale varijable nemaju značajniji utjecaj u razlikovanju skupina.

Potrebno je bilo testirati i razlike između djece s cerebralnom analizom (CP) i djece urednog razvoja (UR) na svakoj pojedinoj manifestnoj varijabli artikulacijskih i fonoloških sposobnosti ove djece. Budući da je varijabla TESTA (broj artikulacijskih grešaka) intervalna, moguće je bilo primijeniti parametrijske statističke metode. S obzirom da distribucija frekvencija kod djece urednog razvoja nije normalna te da se radi o malom uzorku ispitanika bilo je moguće primijeniti Cochran-Cox metodu za testiranje razlika između aritmetičkih sredina malih nezavisnih uzoraka (Petz i suradnici, 2012.).

Dobiven je test razlika između aritmetičkih sredina tg $=4,14$ koji je značajan na razini značajnosti $\mathrm{p}(\operatorname{tg})=0,001$ odnosno $\mathrm{p}(\operatorname{tg})=0,1 \%$ (Tablica 5.) te ukazuje na statistički značajne razlike između djece s cerebralnom paralizom (CP) i djece urednog razvoja (UR) u broju artikulacijskih grešaka. Djeca s cerebralnom paralizom čine 4 puta više artikulacijskih grešaka od djece urednog razvoja.

Tablica 5. Razlike između djece s cerebralnom paralizom (CP) $i$ djece urednog razvoja (UR) u broju artikulacijskih grešaka (TESTA), Cochran-Cox metodom

\begin{tabular}{|c|c|c|c|c|c|c|c|c|}
\hline \multirow{2}{*}{ Varijabla } & \multicolumn{2}{|c|}{ Aritmetičke sredine } & \multicolumn{2}{|c|}{ Standardne devijacije } & t & p(t) & tg & p(tg) \\
\cline { 2 - 5 } & CP & UR & CP & UR & & & & \\
\hline TESTA & 20,87 & 4,73 & 9,34 & 5,50 & 5,76 & 0,000 & 4,14 & 0,001 \\
\hline
\end{tabular}


Fonološke varijable su dihotomne pa su razlike između djece s cerebralnom paralizom i djece urednog razvoja, na svakoj fonološkoj varijabli, testirane primjenom Hi-kvadrat testa, a zbog tablica $2 \times 2$ potrebno je bilo uzeti u obzir i Jejtsovu korekciju (Yates' Correction for Continuity), što znači da se navode i tumače rezultati Continuity Correction (Pallant, 2007), dobiveni u SPSS-u. Rezultati testiranja razlika između djece s CP i djece UR na fonološkim varijablama nadovezuju se na Tablicu 2, a prikazani su u Tablici 6.

Rezultati ukazuju na statistički značajne razlike $\mathrm{u}$ fonološkim greškama između djece s cerebralnom (CP) i djece urednog razvoja (UR), temeljem vrijednosti Hi-kvadrat testa na varijablama (Asymp. Sig. < 5\%): TRAR (traženje rime), gdje je p1=0,025, IZPG (izdvajanje početnoga glasa), gdje je $\mathrm{p} 1=0,000$, FONAN (fonemska analiza), gdje je p1=0,020 i BRISK (brisanje konsonanata), gdje je p1=0,000. Međutim, uzimajući u obzir Yates-ovu korekciju statistički značajne razlike dobivene su samo na varijablama: IZPG (izdvajanje početnoga glasa), gdje je p2=0,001 i BRISK (brisanje konsonanata), gdje je $\mathrm{p} 2=0,000$.

Kod ostalih fonoloških varijabli nisu dobivene statistički značajne razlike između djece s cerebralnom (CP) i djece urednog razvoja (UR), jer je Asymp.Sig. $>5 \%$.

Dobiveni rezultati uglavnom su i očekivani s obzirom na hijerarhiju razvoja navedenih vještina u djeteta. Ivšac Pavliša i Lenček (2011) navode da se razvoj fonološke svjesnosti ne odvija prema "sve ili ništa" principu već postoji slijed odnosno razine koje idu od svjesnosti većih jedinica (slogova, onse$t a$, rima) do više razine osjetljivosti o postojanju malih jedinica (fonemi) u svim pozicijama unutar riječi. U tom smjeru tumačimo i dobivene rezultate, te je stoga najteži zadatak brisanja konsonanata a najlakši ponavljanje riječi i ponavljanje pseudoriječi. Nadalje, zadatak brisanja konsonanata smatran je najtežim zadatkom jer on zahtijeva i vrlo složenu kognitivnu obradu. To je zadatak koji zahtijeva više istovremenih kognitivnih operacija - glasovnu analizu zadane riječi, sposobnost ekstrahiranja glasa, ponovnu sintezu dobivene riječi te pridavanje značenja istoj. Dakle, kognitivno vrlo zahtjevan zadatak koji ipak nije predstavljao problem skupini urednog razvoja, ali skupini djece s cerebralnom paralizom jest. Po tom principu slijedi vrlo težak zadatak izdvajanja prvog glasa u riječi te fonemska analiza za koju Anthony i Francis (2005) navode da je teža od fonemske sinteze te da u razvojnom slijedu djeca prvo stapaju fonološke informacije, a tek zatim analiziraju riječi iste jezične složenosti.

Prema hijerarhiji razvoja fonoloških sposobnosti na nižoj razini složenosti nalaze se aktivnosti poput inicijalnog rimovanja, rimovanja pjesama i segmentacije rečenica. Na sredini kontinuuma nalaze se aktivnosti vezane uz segmentaciju riječi na slogove $\mathrm{i}$ spajanje slogova u riječi, a na najvišoj razini fonološke svjesnosti nalazi se fonemska svjesnost kao shvaćanje da su riječi građene od pojedinačnih glasova ili fonema i sposobnost manipulranja tim fonemima $u$ svrhu stvaranja nove riječi (Chard i Dickson, 1999) što se upravo pokazalo i u ovom ispitivanju.

Iz svih navedenih rezultata vidljivo je da postoje značajne razlike između ispitanika s cerebralnom paralizom i njihovih vršnjaka urednoga razvoja. Postignuti rezultati pokazuju općenito slabije postignuće ispitanika s cerebralnom paralizom na

Tablica 6. Razlike između djece s cerebralnom paralizom (CP) i djece urednog razvoja (UR) na fonološkim varijablama

\begin{tabular}{|l|c|c|c|c|c|}
\hline Varijable & $\begin{array}{c}\text { Pearson } \\
\text { Hi-kvadrat }\end{array}$ & $\begin{array}{c}\text { Stupnjevi } \\
\text { slobode }\end{array}$ & $\begin{array}{c}\text { Asymp.Sig. } \\
\text { (2-sided) } \\
\text { p1 }\end{array}$ & $\begin{array}{c}\text { Continuity } \\
\text { Correction }\end{array}$ & $\begin{array}{c}\text { Asymp.Sig. } \\
\text { (2-sided) } \\
\text { p2 }\end{array}$ \\
\hline PONAR- ponavljanje riječi & 2,14 & 1 & 0,143 & 0,54 & 0,464 \\
\hline PONAL- ponavljanje logatoma & 2,14 & 1 & 0,143 & 1,21 & 0,272 \\
\hline TRAR- traženje rime & 5,00 & 1 & 0,025 & 3,47 & 0,062 \\
\hline IZPG- izdvajanje početnoga glasa & 12,86 & 1 & 0,000 & $\mathbf{1 0 , 1 6}$ & $\mathbf{0 , 0 0 1}$ \\
\hline RASTS- rastavljanje na slogove & 2,16 & 1 & 0,142 & 0,96 & 0,327 \\
\hline FONAN- fonemska analiza & 5,40 & 1 & 0,020 & 3,75 & 0,053 \\
\hline FONSI- fonemska sinteza & 3,33 & 1 & 0,068 & 1,48 & 0,224 \\
\hline BRISK- brisanje konsonanata & 17,37 & 1 & 0,000 & $\mathbf{1 4 , 3 5}$ & $\mathbf{0 , 0 0 0}$ \\
\hline
\end{tabular}


Tablica 7. Rezultati robusne diskriminacijske analize između djece s cerebralnom paralizom spastičnog tipa (SCP) $i$ djece s cerebralnom paralizom atetotičnog tipa $(A C P)$

\begin{tabular}{|c|c|c|c|c|c|c|c|}
\hline \multicolumn{2}{|c|}{ Diskriminacijska } & \multicolumn{2}{|c|}{$\begin{array}{c}\text { Aritmetičke sredine } \\
\text { (Centroidi) }\end{array}$} & \multicolumn{2}{c|}{ Standardne devijacije } & \multirow{2}{*}{ F } & \multirow{2}{*}{ z } \\
funkčajnost \\
\cline { 1 - 4 } funkija & vrijednost & SCP (1) & ACP (2) & SCP (1) & ACP (2) & & \\
\hline
\end{tabular}

Tablica 8. Struktura diskriminacijske funkcije s obzirom na vrstu cerebralne paralize.

\begin{tabular}{|l|c|c|}
\hline Varijable & $\begin{array}{c}\text { Diskriminacijski } \\
\text { koeficijenti }\end{array}$ & $\begin{array}{c}\text { Korelacije s diskr. } \\
\text { funkcijom }\end{array}$ \\
\hline TESTA & $\mathbf{- 0 , 4 3}$ & $\mathbf{- 0 , 5 3}$ \\
\hline PONAR & 0,12 & 0,38 \\
\hline PONAL & 0,00 & 0,41 \\
\hline TRAR & $\mathbf{0 , 2 6}$ & $\mathbf{0 , 6 1}$ \\
\hline IZPG & 0,00 & 0,34 \\
\hline RASTS & $\mathbf{0 , 4 8}$ & $\mathbf{0 , 7 6}$ \\
\hline FONAN & $\mathbf{0 , 6 0}$ & $\mathbf{0 , 8 6}$ \\
\hline FONSI & 0,00 & 0,46 \\
\hline BRISK & $\mathbf{0 , 3 8}$ & $\mathbf{0 , 7 4}$ \\
\hline
\end{tabular}

zadatcima fonološke svjesnosti, a naglašena inferiornost je upravo na zadacima više razine. Manje su sposobni manipulirati glasovima što djelomično može biti posljedica i usporene maturacije.

Pretpostavlja se da djeca postaju svjesnija jedinica manjih od slogova u trenutku kada njihov rječnik dosegne opseg koji omogućava učinkovite načine pohranjivanja i prizivanja informacija (Fernandez-Fein i Baker, 1997) te je moguće pretpostaviti da su dobiveni rezultati u skupini djece s cerebralnom paralizom posljedica i nedostataka u pohranjivanju i prizivanju jezičnih informacija.

\section{Razlike u artikulacijskim i fonološkim sposobnostima kod djece s obzirom na vrstu cerebralne paralize (CP)}

U svrhu testiranja hipoteze $\mathrm{H} 2$ korištena je diskriminacijska analiza. Podaci su obrađeni programom za robusnu diskriminacijsku analizu ROBDIS (Nikolić, 1991, prema Mejovšek, 2013).

Potrebno je bilo utvrditi postoje li statistički značajne razlike između djece s cerebralnom paralizom spastičnog tipa (SCP) i djece s cerebralnom paralizom atetotičnog tipa (ACP) na cjelokupnom prostoru artikulacijskih i fonoloških varijabli. Rezultati ove analize prikazani su u Tablici 7.

Ekstrahirana je jedna diskriminacijska funkcija koja je značajna na razini $\mathrm{p}=0,1 \%$, Rezultati potvrđuju pretpostavku H2 o statistički značajnim razlikama u artikulacijskim i fonološkim sposobnostima između djece s cerebralnom paralizom spastičnog tipa (SCP) i djece s cerebralnom paralizom atetotičnog tipa (ACP). Veći prosječan rezultat postigla su djeca s cerebralnom paralizom spastičnog tipa $(0,79$ standardnih devijacija) od djece s cerebralnom paralizom atetotičnog tipa (ACP) (-1,57 standardnih devijacija). U definiranju diskriminacijske funkcije najviše sudjeluje varijabla fonemska analiza (FONAN) s diskriminacijskim koeficijentom 0,60 i vrlo visokom korelacijom s diskriminacijskom funkcijom od 0,86. Značajan doprinos diskriminativnoj funkciji daju i varijabla RASTS (rastavljanje na slogove), TESTA (broja artikulacijskih pogrešaka), brisanje konsonanata (BRISK) te varijabla traženje rime (TRAR) (Tablica 8).

Ostale varijable imaju vrlo mali učinak u kreiranju diskriminacijske funkcije.

Također smo testirati razlike između skupina na svakoj pojedinoj manifestnoj varijabli artikulacijskih i fonoloških sposobnosti ove djece. Značajnost razlika za varijablu TESTA (broj artikulacijskih grešaka) testirana je primijenom Cochran-Cox metode. Dobivena vrijednost testa razlika između aritmetičkih sredina $\operatorname{tg}=1,97$ nije značajna na razini značajnosti $\mathrm{p}(\operatorname{tg})=0,068$ odnosno $\mathrm{p}(\operatorname{tg})=6,8 \%$.( Tablici 9).

Tablica 9. Razlike između djece s cerebralnom paralizom spastičnog tipa (SCP) i djece s cerebralnom paralizom astetičnog tipa (ACP) u broju artikulacijskih grě̌aka (TESTA), Cochran-Cox metoda

\begin{tabular}{|c|c|c|c|c|c|c|c|c|}
\hline \multirow[t]{2}{*}{ Varijabla } & \multicolumn{2}{|c|}{ Aritmetičke sredine } & \multicolumn{2}{|c|}{ Standardne devijacije } & \multirow[t]{2}{*}{$\mathbf{t}$} & \multirow[t]{2}{*}{$p(t)$} & \multirow[t]{2}{*}{$\operatorname{tg}$} & \multirow[t]{2}{*}{$p(\operatorname{tg})$} \\
\hline & (SCP) & (ACP) & (SCP) & $(\mathrm{ACP})$ & & & & \\
\hline TESTA & 17,70 & 27,20 & 9,28 & 5,42 & 1,97 & 0,068 & 1,97 & 0,068 \\
\hline
\end{tabular}


Emica Farago, Draženka Blaži, Martina Vuković Ogrizek: Artikulacijsko-fonološke sposobnosti djece s cerebralnom paralizom

Tablica 10. Frekvencije i postoci odgovora te razlike između djece s cerebralnom paralizom spastičnog tipa (SCP) i djece s cerebralnom paralizom astetičnog tipa (ACP), na fonološkim varijablama

\begin{tabular}{|l|c|c|c|c|c|c|}
\hline & \multicolumn{2}{|c|}{$\begin{array}{c}\text { SCP } \\
\text { frekvencija/ } \\
\text { postotak }\end{array}$} & \multicolumn{2}{c|}{$\begin{array}{c}\text { ACP } \\
\text { frekvencija/ } \\
\text { postotak }\end{array}$} & $\begin{array}{c}\text { Continuity } \\
\text { Correction }\end{array}$ & $\begin{array}{c}\text { Asymp.Sig. } \\
\text { (2-sided) } \\
\text { p }\end{array}$ \\
\cline { 2 - 6 } & 2-nema grešku & \\
\hline PONAR- ponavljanje riječi & $1 / 10$ & $9 / 90$ & $1 / 20$ & $4 / 80$ & 0,00 & 1,000 \\
\hline PONAL- ponavljanje logatoma & $6 / 60$ & $4 / 40$ & $3 / 60$ & $2 / 40$ & 0,00 & 1,000 \\
\hline TRAR- traženje rime & $5 / 50$ & $5 / 50$ & $4 / 80$ & $1 / 20$ & 0,31 & 0,576 \\
\hline IZPG- izdvajanje početnoga glasa & $6 / 60$ & $4 / 40$ & $3 / 60$ & $2 / 40$ & 0,00 & 1,000 \\
\hline RASTS- rastavljanje na slogove & $1 / 10$ & $9 / 90$ & $3 / 60$ & $2 / 40$ & 2,09 & 0,148 \\
\hline FONAN- fonemska analiza & $3 / 30$ & $7 / 70$ & $5 / 100$ & $0 / 0$ & 4,05 & 0,044 \\
\hline FONSI- fonemska sinteza & $2 / 20$ & $8 / 80$ & $1 / 20$ & $4 / 80$ & 0,00 & 1,000 \\
\hline BRISK- brisanje konsonanata & $6 / 60$ & $4 / 40$ & $5 / 100$ & $0 / 0$ & 1,07 & 0,302 \\
\hline
\end{tabular}

Unatoč prosječno boljim artikulacijskim sposobnostima djece sa spastičnim tipom cerebralne paralize (SCP) u odnosu na skupinu djece s atetotičnim tipom cerebralne paralize (ACP) koja su prosječno napravila 27,20 pogrešaka nisu dostignute vrijednosti koje bi potvrdile statističku značajnost razlika u broju artikulacijskih grešaka, budući da je $p>5 \%$.

Razlike između skupina djece na svakoj fonološkoj varijabli, testirali smo i primjenom Hi-kvadrat testa. Također, i ovdje je uzeta u obzir Jejtsova korekcija ( Tablici 10).

Statistički značajne razlike $u$ fonološkim varijablama između djece SCP skupine i djece ACP skupine, dobivene su samo na varijabli FONAN (fonemska analiza), gdje je $\mathrm{p}=0,044$. Kod ostalih fonoloških varijabli nisu dobivene statistički značajne razlike jer je Asymp.Sig. $>5 \%$.

Također se može uočiti da je skupina s atetozom (ACP) imala više teškoća u svim zadacima, a najvišu razinu uspješnosti ova skupina je pokazala u ponavljanju riječi (PONAR) i fonemskoj sintezi (FONSI), a najteži su se pokazali zadaci fonemske analize (FONAN) i brisanja konsonanata (BRISK). Unatoč slabijoj uspješnosti ispitanika s atetozom te razlike dostižu statističku značajnost samo pri fonemskoj analizi koja je ovim ispitanicima bila teška i niti jedan ispitanik nije uspješno rastavio riječ na foneme.

Razlika između ispitanika s cerebralnom paralizom s obzirom na vrstu oštećenja u korist ispitanika sa spastičnom cerebralnom paralizom jednim je dijelom bila očekivana jer su ispitanici sa spastičnom paralizom (SCP) imali manja "fizička" oštećenja (čak dvoje hoda samostalno, a troje uz pomoć), dok su svi ispitanici s atetotičnom cerebralnom paralizom (ACP) u kolicima, a samo jedan hoda. Djeca sa spastičnim tipom CP blaže do srednjeg stupnja kvadriplegije mogu razviti govornu produkciju relativno rano. Njihove artikulacijske sposobnosti su relativno dobre, ali uslijed primarnog stanja mogu biti zahvaćeni i neki drugi sustavi koji se mogu reflektirati i na artikulacijske sposobnosti. Mišićne disfunkcije u području gornjeg dijela trupa mogu dovesti do respiracijskih teškoća koje su povezane s govornom produkcijom, odnosno artikulacijom i kvalitetom glasa. Naravno, konačna slika govorne produkcije ovisi o stupnju i ekstenziji lezije (Pirila, 2007), odnosno u relaciji je s topografskom distribucijom neuromotoričkog oštećenja. Zbog osnovnog stanja moguće je da dijete s diplegijom ili kvadriplegijom spastičnog oblika više vremena provodi u lošoj posturi što se može negativno odraziti na kvalitetu govorne produkcije, dapače može dovesti i do regresije u govornoj produkciji. S druge strane kod djece $\mathrm{s}$ atetozom prisutni su i nevoljni pokreti koji se pojačavaju pri voljnim aktivnostima pa utječu i na kvalitetu govorne produkcije. Nevoljni pokreti zahvaćaju cijelo tijelo i djeluju kao buka, ili šum pa je moguće da utječu na uspješnost motoričkog učenja i slušanje, a time i na teškoće u razvoju fonoloških vještina i govorni inteligibilitet.

\section{ZAKLJUČAK}

Kako je već ranije navedeno, govorna produkcija jedan je od najvažnijih čimbenika u razvoju 
djeteta koji određuje njegove kasnije socijalne obrasce. Govorom dijete usvaja znanja i navike potrebne za svakodnevni život, stječe različite sposobnosti i ulazi u društvo kao njegov sastavni dio.

Usvajanje izgovora je vrlo važan dio razvoja svakog pojedinca jer ako u tom razvoju dođe do zaostajanja javljaju se greške izgovora koje, ne samo da ometaju razumljivost govora i utječu na govornika i njegovo samopouzdanje, već ometaju i slušača, koji uočavajući greške izgovora, ne sluša sadržaj govornikova izričaja nego usmjerava pažnju na način njegova govora i time dolazi do nesporazuma u komunikaciji. Uz usvajanje izgovora za djetetov razvoj, jednako je važan i fonološki razvoj.

Provedenim istraživanjem zaključeno je da između djece s cerebralnom paralizom i njihovih vršnjaka urednoga razvoja postoje statistički značajne razlike kako u artikulacijskim tako i u dijelu fonoloških sposobnosti. Istraživanje je potvrdilo da ispitanici s cerebralnom paralizom čine iste tipove grešaka kao i djeca urednoga razvoja, no frekvencija grešaka je znatno veća nego li u skupini vršnjaka.

U prostoru fonoloških sposobnosti razlike su naglašeno prisutne u zadatcima koji zahtijevaju složeniju razinu kognitivne obrade, npr. brisanja konsonanata za koje se i očekivalo da će biti teži. Značajna latentna razlika pronađena je i na zadacima traženja rime i fonemske analize. Uz osnovno stanje skupine s cerebralnom paralizom koja je bila intelektualno urednog statusa lošiji rezultati se mogu dijelom pripisati i njihovom iskustvu. Tijekom ispitivanja primijećena je velika razlika u poznavanju i prepoznavanju ponuđenog sadržaja između djece s cerebralnom paralizom i njihovih vršnjaka urednog razvoja, što navodi na zaključak da djeca s cerebralnom paralizom zbog svojih motoričkih ograničenja imaju i ograničenu razinu iskustva u relaciji s vršnjacima urednog razvoja. Naši rezultati su potvrdili da tip motoričkog ograničenja može biti važan čimbenik u razvoju artikulacijskih i fonoloških sposobnosti. Ispitanici sa spastičnim oblikom cerebralne paralize imali su manje pogrešaka pri artikulaciji glasova i bili su uspješniji u zadatcima koji ispituju neke aspekte fonoloških sposobnosti (fonemska analiza i rastavljanje na slogove). Osobe s cerebralnom paralizom generalno pokazuju lošije rezultate u govornoj produkciji, ali i u fonološkim vještinama čak i niže zahtjevnosti što ukazuje na potrebu što ranije intervencije i intezivnije strukturirano poticanje u cilju razvoja fonoloških vještina kao bitnih čimbenika u razvoju govornog i pisanog jezika, a koje se često zanemaruju u predškolskom razdoblju. 


\section{LITERATURA}

Anthony, J.L., Francis D.J. (2005). Development of Phonological Awareness, Current directions in psychological science, American PsychologicalSociety, Volume 14, Number 5, 255-258.

Apel, K., Masterson, J., \& Hart, P. (2004). Integration of language components in spelling: Instruction that maximizes students' learning. U: E. Silliman \& L. Wilkinson (Eds.).

Bax, M., Goldstein, M., Rosenbaum, P., Leviton, A., Paneth, N., Dan, B., Jacobsson, B., Damiano, D. (2005). Proposed definition and classification of cerebral palsy. Developmental Medicine and Child Neurology, 47, 8, 571-576.

Blaži D., Vancaš, M., Prizl-Jakovac, T. (2000). Fonološki poremećaji i fonemska diskriminacija u predškolske djece. Hrvatska revija za rehabilitacijska istraživanja 36, 2, 165-168.

Blaži, D., Buzdum, I., Kozarić-Ciković, M. (2011). Povezanost uspješnosti vještine čitanja s nekim aspektima fonološkog razvoja, Hrvatska revija za rehabilitacijska istraživanja 2011, Vol 47, br. 2, str. 14-25.

Bowen, C. (1998a). Developmental phonological disorders: Information for families. http://www.speechlanguagetherapy.com/parentinfo.html, 1.7. 2010.

Bowen, C. (1998b). Children speech and sound disorders: Questions and answers. http://speech-language-therapy. com/phonol-and-artic.htm, 1.7.2010.

Cowan, W.E., \& Moran, M.J. (1997). Phonological awareness skills of children with articulation disorders in kindergarten to third grade. Journal of Children's Communication Development, 18, 31-38.

Chard, D.J., Dickson, S.V. (1999). Phonological Awareness: Instructional and Assessment Guidelines. Intervention in School and Clinic 34, 261-270.

Fernandez-Fein, S. i Baker, L. (1997). Rhyme and alliteration sensitivity and relevant experiences among reschoolers from diverse backgrounds. Journal of Literacy Research, 29 (3): 433-459.

Honda, M. (2003). Human Speech Production Mechanisms. NTT Technical Review 1(2), 24-29; www.analogue.org/ network.

Himmelmann, K., Hagberg, G., Uvebrant, P. (2010). The changing panorama of cerebral palsy in Sweden. X. Prevalence and origin in the birth-year period 1999-2002. Acta Paediatrica, 99, 1337-134.

Ivšac Pavliša, J., Lenček, M. (2011). Fonološke vještine i fonološko pamćenje: neke razlike između djece urednoga jezičnoga razvoja djece s perinatalnim oštećenjem mozga i djece s posebnim jezičnim teškoćama kao temeljni prediktor čitanja, Hrvatska revija za rehabilitacijska istraživanja, 47, 1, 1-16.

Kirby, J.R.; Pfeiffer, S.; Parilla, R. (2003). Naming speed and phonologicalawareness as predictors of Reading Development. Journal of EducationalPsychology 95, 453-464.

Kirinčić, N., Paučić-Kirinčić, E., Jurčić, M. (1992). Govorne smetnje u djece oboljele od cerebralne paralize. Medicina 28, 185-187.

Križ, M., Prpić, I. (2005). Cerebralna paraliza. Medicina 42, 41, 64-68.

Lenček, M., Blaži, D., Ivšac, J. (2007). Specifične teškoće učenja: Osvrt na probleme u jeziku, čitanju i pisanju. Magistra Iadertina. 2 , 2, 107-121.

Mejovšek, M. (2013). Metode znanstvenog istraživanja u društvenim i humanističkim znanostima, Naklada Slap. Jastrebarsko.

Menyuk, P., Chesnick, M. (1997). Metalinguistic skills, oral language knowledge, and reading. Topics-in-LanguageDisorders, 17, 3, 75-87.

Munson, B., Edwards, J., Becman, M.E. (2005a). Phonological knowledge in typical and atypical speech sound development. Topics in Language Disorders, 25, 3, 190 - 206.

Munson, B., Edwards, J., Becman, M.E. (2005b). Relationships between nonword repetition accuracy and other 
measure of linguistic development in children with phonological disorders. Journal of Speech, Language and Hearing Research, 48, 1, 61-78.

Nicholson, T. (1997). Closing the gap on reading failure: Social back-ground, honemic awareness, and learning to read. U B. Blachman (Ed.), Foundations of reading acquisition and dyslexia: Implications for early intervention, 381-408.

Nordberg, A. (2015). Speech, Language and Communicative Ability in School-Aged Children with Cerebral Palsy and Speech Impairment. University of Gothenburg. Ineko, Gothenburg.

Nordberg, A., Miniscalco, C., Lohmander, A. (2014). Consonant production and overall speech characteristics in school-aged children with cerebral palsy and speech impairment. International Journal of Speech-Language Pathology, 16, 4, 386-395.

Pallant, J. (2007). SPSS Survival Manual: A Step by Step Guide to Data Analysis using SPSS for Windows, 3rd edition, Open University Press.

Peeters, M., Verhoeven, L., Balkom, van H.., J. de Moor. (2008). Phonological awareness, foundation measures and cerebral palsy. Journal of Intellectual Disability Research, 52, 3, 68-78.

Pennington, L. (2008). Cerebral palsy and communication. Paediatrics and Child Health, 18, 9, 405-409.

Petz B., Kolesarić, V., Ivanec, D. (2012). Petzova statistika. Naklada slap. Jastrebarsko.

Pirila, S., Van der Meere, J., Pentikainen, T., Ruusu-Niemi, P., Korpela, R., Kilpinen, J., Nieminen, P. (2007). Language and motor speech skills in children with cerebral palsy. Journal of Communication Disorders, 40, 116-128.

Pospiš, M. (2005). Cerebralna paraliza i teškoće u učenju. Međunarodni simpozij o cerebralnoj paralizi 30. rujna - 2. listopada 2004., Pula, Hrvatska. Zagreb: HSUCDP.

Rvachew, S., Ohberg, A., Grawburg, M., \& Heyding, J.(2003). Phonological awareness and phonemic perception in 4-year-old children with delayed expressive phonology skills. American Journal of Speech-Language Pathology, $12,463-471$.

Storkel, H. L., Hoover, J. R. (2009). Word learning by children with phonological delays: Differentiating effects of phonotactic probability and neighborhood density. University of Kansas.Kansas.

Vancaš, M., Ivšac, J. (2004). Ima neka tajna (?) veza: jezik - čitanje - pisanje. Dijete, odgojitelj i učitelj - Zbornik radova znanstveno - stručnog skupa. Sveučilište u Zadru. Zadar. 103-115.

Vuletić, D. (1990). Test artikulacije. Fakultet za defektologiju Sveučilišta u Zagrebu, Zagreb.

\title{
ARTICULATION AND PHONOLOGICAL ABILITIES OF CHILDREN WITH CEREBRAL PALSY
}

\begin{abstract}
The goal of this research was to examine and compare articulation and phonological abilities in children with cerebral palsy and their typically developing peers. An examination was conducted on a sample of 15 children with cerebral palsy and 15 typically developing children. The two groups were equalized by gender and age. The measuring instruments used were the Articulation Test and phonological ability tasks. The data were analysed using the robust discriminative analysis, $t$-test, chisquare test, as well as the Cohran-Cox test. The results showed a significant statistical difference in articulation and phonological abilities between children with cerebral palsy and typically developing children. The difference between the groups is for the most part due to the variables deletion of consonants and number of articulation errors. The variables first voice segregation, phonemic analysis, and rhyme searching are also significant in creating this discriminant function.

The results also confirm statistical differences in articulation and phonological abilities that are related to the type of cerebral palsy. A group of children with a spastic type of cerebral palsy was more successful in phoneme analysis, syllable analysis, consonant deletion tasks, and rhyme searching tasks. They also had better articulation abilities.
\end{abstract}

Key words: cerebral palsy, phonological abilities, articulation 